\title{
EFFICACY OF THE CLINICAL-INSTRUMENTAL ALGORITHM IN THE TREATMENT OF SPINAL TANDEM STENOSIS
}

\author{
EFICÁCIA DO ALGORITMO CLÍNICO-INSTRUMENTAL NO TRATAMENTO DA ESTENOSE \\ ESPINHAL EM TANDEM
}
EFICACIA DEL ALGORITMO CLINICO-INSTRUMENTAL EN EL TRATAMIENTO DE LA ESTENOSIS ESPINAL EN TÁNDEM

\author{
1. Irkutsk State Medical University, Irkutsk, Russia. \\ 2. Railway Clinical Hospital on the station Irkutsk-Passenger of Russian Railways Ltd., Irkutsk, Russia. \\ 3. Irkutsk Scientific Center of Surgery and Traumatology, Irkutsk, Russia. \\ 4. Irkutsk State Medical Academy of Continuing Education, Irkutsk, Russia. \\ 5. 1477 Naval Clinical Hospital, Vladivostok, Russia.
}

Vadim Anatol'eVich ByvaltseV, ${ }^{1,2,3,4}$ Andrei Andreevich Kalinin, ${ }^{1,2}$ Valeril Vladimirovich ShepeleV, $^{1,5}$ Yuril Yakovlevich Pestryakov $^{1}$

\begin{abstract}
Objective: To conduct a multicenter analysis of the effectiveness of surgical tactics for treating patients with symptomatic tandem stenosis of the cervical and lumbar spine, based on a differentiated clinical-instrumental algorithm. Methods: The study included 97 patients with symptomatic tandem stenosis of the cervical and lumbar spine. The patients were allocated into 2 groups. The main prospective follow-up group (Group I) consisted of patients $(n=46)$ who had undergone staged decompression/stabilization surgery according to the surgical tactics developed based on the differential clinical-instrumental algorithm. The clinical comparison group (Group II) ( $n=51)$ consisted of retrospectively recruited patients who, depending on the prevailing clinical condition, underwent primary surgery at the cervical level (29 cases) or at the lumbar level (22 cases). Results: The comparative analysis in Group I revealed significantly better parameters in the clinical and instrumental data. The total rates of postoperative surgical complications in the cervical and lumbar spine were 15\% in Group I and $68 \%$ in Group II $(p=0.0014)$. Conclusion: The multicenter analysis of the clinical-instrumental algorithm based on differential application of decompression/stabilization techniques enabled more rational and radical surgery, with less adverse outcomes, leading to earlier start of rehabilitation in the prospective group of patients (Group I), and an objective improvement in long-term clinical and functional outcomes. Level of Evidence II; Prognostic Studies - Investigating the Effect of a Patient Characteristic on Disease Outcome.
\end{abstract}

Keywords: Spinal stenoses; Chronic disease; Diagnosis; Decompression; Spinal fusion.

\section{RESUMO}

Objetivo: Realizar uma análise multicêntrica da eficácia das táticas cirúrgicas no tratamento de pacientes com estenose sintomática em tandem da coluna cervical e lombar com base em um algoritmo clínico-instrumental diferenciado. Métodos: O estudo incluiu 97 pacientes com estenose sintomática em tandem da coluna cervical e lombar. Os pacientes foram divididos em 2 grupos. O grupo de acompanhamento prospectivo principal (Grupo 1) incluiu pacientes $(n=46)$ submetidos à cirurgia de descompressão/estabilização estagiada de acordo com as táticas cirúrgicas desenvolvidas com base no algoritmo clínico-instrumental diferencial. O grupo de comparação clínica (Grupo II) (n = 51) incluiu pacientes recrutados retrospectivamente que, dependendo do quadro clínico vigente, foram submetidos à cirurgia primária em nível cervical (29 casos) ou em nível lombar (22 casos). Resultados: A análise comparativa no Grupo I revelou parâmetros significativamente melhores nos dados clínicos e instrumentais. As taxas totais de complicações cirúrgicas pós-operatórias na coluna cervical e lombar foram de 15\% no Grupo I e 68\% no Grupo II ( $p=0,0014)$. Conclusão: A análise multicêntrica do algoritmo clínico-instrumental baseada na aplicação diferencial das técnicas de descompressão/estabilização permitiu uma cirurgia mais racional e radical com menos desfechos adversos, levando a um início mais precoce de reabilitação no grupo prospectivo de pacientes (Grupo I) e uma melhora concreta nos desfechos clínicos e funcionais a longo prazo. Nível de Evidência II; Estudos prognósticos - Investigação do efeito de característica de um paciente sobre o desfecho da doença.

Descritores: Estenose espinal; Doença crônica; Diagnóstico; Descompressão; Fusão espinhal.

\section{RESUMEN}

Objetivo: Realizar un análisis multicéntrico de la eficacia de las tácticas quirúrgicas en el tratamiento de pacientes con estenosis sintomática en tándem de la columna cervical y lumbar con base en un algoritmo clínico-instrumental diferenciado. Métodos: El estudio incluyó a 97 pacientes con estenosis sintomática en tándem de la columna cervical y lumbar. Los pacientes fueron divididos en 2 grupos. El grupo de acompañamiento prospectivo principal (Grupo I) incluyó a pacientes $(n=46)$ sometidos a cirugía de descompresión/ estabilización por etapas de acuerdo con las tácticas quirúrgicas desarrolladas basadas en el algoritmo clínico-instrumental diferencial. El grupo de comparación clínica (Grupo II) $(n=51)$ incluyó a pacientes reclutados retrospectivamente que, dependiendo del cuadro clínico vigente, fueron sometidos a cirugía primaria en nivel cervical (29 casos) o en nivel lumbar (22 casos). Resultados: El análisis comparativo en el Grupo I reveló parámetros significativamente mejores en los datos clínicos e instrumentales. Las tasas totales de complicaciones 
quirúrgicas postoperatorias en la columna cervical y lumbar fueron de 15\% en el Grupo / y 68\% en el Grupo /l (p = 0,0014). Conclusión: El análisis multicéntrico del algoritmo clínico-instrumental basado en la aplicación diferencial de las técnicas de descompresión/estabilización permitió una cirugía más racional y radical con menos resultados adversos, llevando a un inicio más precoz de rehabilitación en el grupo prospectivo de pacientes (Grupo I), y una mejora concreta en los resultados clínicos y funcionales a largo plazo. Nivel de Evidencia II; Estudios pronósticos - Investigación del efecto de característica de un paciente sobre el desenlace de la enfermedad.

Descriptores: Estenosis espinal; Enfermedad crónica; Diagnóstico; Descompresión; Fusión vertebral.

\section{INTRODUCTION}

Degenerative spine diseases, particularly vertebrogenic compression syndromes, and their surgical treatment still remain ones of the most topical issues in neurosurgery, spinal surgery, traumatology, and orthopedics. ${ }^{1-3}$

The multicomponent clinical symptoms and various pathophysiological manifestations of the degenerative process at the cervical and lumbar level occur as isolated or more complex combined tandem stenoses, ${ }^{4,5}$ which is a pathological narrowing of the central spinal canal, lateral recess or intervertebral foramen. ${ }^{6-8}$ Surgical treatment of degenerative spinal stenosis traditionally uses isolated decompression and decompression combined with stabilization of spinal motion segments (SMSs) using implants. ${ }^{2,9,10}$ Conservative treatment of stenosis provides some improvement only in the early stages of the disease. ${ }^{11,12}$ The introduction of minimally invasive microsurgical techniques undoubtedly brought a more positive perspective for the treatment of these patients. ${ }^{13,14}$

A comprehensive clinical evaluation of neurological symptoms directly arising from the degree of narrowing of the vertebral canal and intervertebral foramen combined with tandem stenoses is used to determine the dominant role in the surgical tactics, and the effectiveness of the intervention. ${ }^{4,10,15}$ Neuroimaging techniques have significantly expanded the diagnostic capabilities for early verification of degenerative spinal diseases, which in turn, has led to an increase in the number of surgical interventions for spinal stenosis. ${ }^{16,17}$

However, certain difficulties still remain in diagnosing the disease and choosing objective indications for surgery. The criteria for comparison of clinical neurological symptoms and pathomorphological compression factors of combined tandem stenosis, which are visualized by radiographic techniques, are not fully presented. ${ }^{18,19}$ The course of degenerative spinal disease with a prolonged adaptation response of SMS biomechanics often predetermines surgical failure, due to decompensation of the patient's condition and circulatory disorders in the area of compressed nerve trunks or spinal cord, during surgery. The rate of unsatisfactory outcomes of surgery for degenerative spinal diseases is $28.3-53 \%$. The rate of disease recurrence due to failed back surgery syndrome is $25 \%$, and in such cases, a new surgical intervention is required. ${ }^{20,21}$ This scenario calls for more in-depth study of the formation of tandem stenoses of the vertebral canal of degenerative genesis, and for the development of objective criteria for preoperative diagnosis and surgical tactics.

A detailed study of the unsatisfactory outcomes of retrospectively diagnosed vertebral canal tandem stenoses was conducted at the Neurosurgery Center of the "Railway Clinical Hospital" at the Irkutsk-Passenger Railway station of the Russian Railways (Irkutsk, Russian Federation). A direct correlation was revealed between unfavorable long-term clinical outcomes and the primary operative intervention on the lumbar spine, the time interval between the stages of surgical interventions, the severity of intracanal scarring, and the development of pseudoarthrosis in the operated segments. ${ }^{22}$

In order to optimize surgical outcomes and eliminate potential adverse effects, assessed retrospectively, we proposed a surgical tactic based on a differential clinical-instrumental algorithm for treating patients with symptomatic tandem stenosis of the cervical and lumbar spine. This study is devoted to analyzing the efficacy of the proposed therapeutic-diagnostic tactics.

Thus, the purpose of this study was to perform a multicenter analysis of the efficacy of the surgical tactics based on the differential of a clinical-instrumental algorithm in patients with symptomatic tandem stenosis of the cervical and lumbar spine.

\section{METHODS}

We performed an open, observational, controlled, nonrandomized, multicenter, prospective study.

We developed inclusion and exclusion criteria to form homogeneous study groups.

The inclusion criteria were as follows: symptomatic multiregional stenosis of the cervical (less than $12 \mathrm{~mm}$ in diameter) and lumbar (less than $15 \mathrm{~mm}$ in diameter) spinal canal, foraminic orifice (less than $4 \mathrm{~mm}$ in diameter) in two or more segments due to ossified disc herniation, yellow ligament hypertrophy, and facet joint arthrosis, without taking into account the number of affected segments.

The exclusion criteria were as follows: asymptomatic stenosis of the cervical and lumbar canals, spondylolisthesis, revision decompression/stabilization surgery at the cervical and lumbar levels, and a significant reduction in bone mineral density (osteoporosis).

The study was carried out at the Neurosurgical Center of the Railway Clinical Hospital of the Irkutsk-Passenger Railway Station (Irkutsk, Russian Federation), Neurosurgical Department of the Irkutsk Scientific Center of Surgery and Traumatology (Irkutsk, Russian Federation), and Department of Neurosurgery of the Naval Clinical Hospital 1477 of the Ministry of Defense of the Russian Federation (Vladivostok, Russian Federation).

A surgical approach and direct decompression of nerve structures were performed according to the established neurosurgical standards, using optical magnification, under intraoperative neurophysiological control. In the cervical spine, the left retropharyngeal approach was used to perform discectomy or corpectomy and decompression of the spinal cord and its roots, followed by interbody spondylodesis with placement of a cage, or transbody spondylodesis with a telescopic prosthesis, in some cases supplemented with fixation of the anterior cervical plate. A number of patients underwent posterior decompressive laminectomy with screw fixation via the lateral masses or laminotomy with laminoplasty in the area of stenosis. In the lumbar spine, all patients underwent reconstruction of the spinal canal and interbody spondylodesis: laminectomy with unilateral or bilateral facetectomy, foraminotomy, posterior interbody spondylodesis, and open transpedicular fixation; in a number of cases, the spinal canal was reconstructed through the paramedian approach in volume of facetectomy with or without contralateral foraminotomy; transforaminal interbody spondylodesis was performed with combined transpedicular fixation.

Group I (main group (MG); $n=46$ ) consisted of operated patients on the use of developed surgical tactics. Which was based on a preoperative clinical and instrumental algorithm for the treatment of tandem stenosis of the cervical and lumbar spine. In this case, the primary operation was performed on the cervical spine and the minimum time between stages was no more than 16 days. During anterior compression with the presence of a myelopathic focus, a corpectomy was performed with the installation of a telescopic prosthesis and a discectomy with interbody fusion in the absence of clinical and instrumental signs of myelopathy. With back compression of the spinal cord, a laminectomy with screw fixation was performed for the lateral masses or a laminotomy with laminoplasty with laminoplasty. In the lumbar spine, a laminectomy was performed with bilateral foraminotomy in cases of bilateral symptomatic foraminal stenosis and minimally invasive bilateral foraminotomy from unilateral access in the case of monoradicular symptoms in the presence of radiological signs of bilateral stenosis of the foraminal openings with subsequent interbody fusion according to the TLIF technique and transpedicular stabilization." 
Group II (clinical comparison group (CCG); $n=51$ ) consisted of patients in whom the results of decompression/stabilization surgery were retrospectively evaluated. The patients met all the inclusion and exclusion criteria, and had been operated on previously for the same indications. In the study group, primary decompression/stabilization surgery was performed at the cervical level in 29 patients, with the use of discectomy with interbody spondylodesis and corpectomy with interbody fusion, without taking into account the presence of the myelopathic lesion; surgery was performed at the lumbar level in 22 patients, with a predominantly extended reconstruction of the vertebral canal through the medial access, and interbody fusion according to the PLIF technique.

In all cases, surgery was performed under intravenous anesthesia and artificial ventilation. The surgical stages were performed under fluoroscopic control, with a C-arc and Video recording.

In group I, the clinical parameters were evaluated before surgery, at discharge, and at follow-up examinations at 3, 6, 12, and 24 months after surgery. In group II, clinical data were analyzed before surgery and in the long-term postoperative period after 24 months. The median follow-up was 26 (24\%; 30\%) months in group I and 40 (34\%; 50\%) months in group II.

The efficacy of the developed surgical tactics based on the preoperative clinical-instrumental algorithm for treating patients with symptomatic tandem stenosis of the cervical and lumbar spine was assessed using the following parameters:

- pain severity in the cervical and lumbar spine and upper and lower extremities according to the visual analogue scale (VAS);

- indices for assessing disabilities associated with neck pain (Neck Disability Index (NDI)) and low back pain (Oswestry Disability Index (ODI)), subjective satisfaction with the outcomes of surgical treatment according to the Macnab scale, and objective dynamics of the neurological outcome according to the Nurick scale.

- degree of spondylodesis at the operated level according to the Bridwell scale.

- degenerative changes in the adjacent intervertebral disc (Pfirrmann scale).

The severity of pain in the cervical and lumbar spine and upper and lower extremities, patients quality of life, subjective satisfaction with the surgery, and objective dynamics of neurological symptoms were evaluated by analyzing the patient-reported data.

The above-mentioned study outcomes were recorded in all group 1 patients before surgery, in the early postoperative period, and during control visits at 3, 6, 12, and 24 months after surgery.

Degeneration of adjacent intervertebral discs was assessed using standard T2-weighted MRI scans obtained on a 1.5 T MRI device according to the Pfirrmann scale with co-workers. ${ }^{23}$

The degree of spondylodesis formation was assessed according to the Bridwell scale with co-workers, using MSCT scans obtained on an MSCT device. ${ }^{24}$

The changes in the operated segments were assessed based on neuroimaging data in the long-term postoperative period.

We analyzed patients' sex, age, height, and weight, based on their medical records. The number and type of complications were studied in both the intra- and in postoperative periods.

The study was approved by the ethical committee of the Scientific Center of Reconstructive and Restorative Surgery of the Siberian Branch of the Russian Academy of Medical Sciences (protocol no. 3 of March 13, 2012). Each of the patients enrolled in the study provided written informed consent.

\section{Statistical analysis}

The statistical data were processed using Microsoft Excel and Statistica 8.0. The significance of differences in sample populations was estimated with nonparametric statistical tests; a level of $p<0.05$ was considered as the lower confidence limit. The data were presented as median and interquartile range in the form of $\mathrm{Me}$ (25\%; 75\%). The following nonparametric statistics criteria were used: the Mann-Whitney (MW) test for intergroup comparison, Friedman's criterion for dependent samples, and Pearson chi-square test $\left(\chi^{2}\right)$ for binomial parameters.

\section{RESULTS}

General information on the patients of the studied groups is given in Table 1: mainly males, two periods of adulthood (35-60 yrs), and high nutritional status (body mass index> $25 \mathrm{~kg} / \mathrm{m} 2$ ).

Intergroup comparison of the studied clinical parameters revealed no significant differences in preoperative indicators (Table 2).

After surgical treatment, all patients experienced a significant decrease in the pain intensity both in the cervical spine, from $71 \mathrm{~mm}$ $(66 ; 80)$ to $8 \mathrm{~mm}(8 ; 12)(p=0.002)$, and in the upper extremities, from $85 \mathrm{~mm}(80 ; 87)$ to $8 \mathrm{~mm}(8 ; 10)(p=0.004)$ (Figure 1).

VAS assessment of pain in the lumbar spine and lower extremities showed a significant decrease in the pain severity after surgery $(p<0.001)$ both in the early postoperative period and in the long-term period from $68 \mathrm{~mm}(64 ; 78)$ to $8 \mathrm{~mm}(p=0.003)$. The same was observed in the lower extremities: from $82 \mathrm{~mm}(78 ; 85)$ to $6 \mathrm{~mm}(5 ; 6)$ $(p=0.006)$ on average (Figure 2$)$.

Intergroup comparison of long-term surgical outcomes (pain intensity) in patients with symptomatic tandem stenosis of the cervical and lumbar spine in 24 months after surgery revealed a statistically significant decrease in the pain level in the prospective group of patients operated on using the developed surgical tactics, based on the preoperative clinical-instrumental algorithm $(p<0.05)$ (Table 3).

The analysis of NDI values revealed an improvement in the parameters after surgery, compared to the preoperative level, with the NDI score decreasing from $48(44 ; 48)$ to $12(8 ; 14)(p=0.003)$ (Figure 3$)$.

The analysis of NDI values revealed a positive improvement in functional state after surgery compared to the preoperative

Table 1. Distribution of study patients by sex, age, and body weight.

\begin{tabular}{c|c|c|c|c}
\hline \multicolumn{2}{c|}{ Criteria } & Group I (n=46) & Group II (n= 51) & $\mathbf{p}^{*}$ \\
\hline \multirow{2}{*}{ Age, years, Me } & $51(48 ; 56)$ & $55(47 ; 59)$ & 0.36 \\
\hline \multirow{2}{*}{ Aex } & Males, n (\%) & $31(67 \%)$ & $36(70 \%)$ & \multirow{2}{*}{0.54} \\
\cline { 2 - 4 } & Females, n (\%) & $15(33 \%)$ & $15(30 \%)$ & \\
\hline
\end{tabular}

\begin{tabular}{|l|l|l|l|l}
\hline Body weight index, $\mathrm{kg} / \mathrm{m}^{2}, \mathrm{Me}$ & $26.4(23.9 ; 29.2)$ & $26.9(23.6 ; 29.8)$ & 0.22 \\
\hline
\end{tabular} Note: $p^{*}$ is the confidence probability.

Table 2. Preoperative clinical parameters in the study group patients.

\begin{tabular}{c|c|c|c}
\hline Criteria & Group I (n= 46) & Group II (n= 51) & $\mathbf{p}^{*}$ \\
\hline VAS, cervical spine, mm, Me & $71 \mathrm{~mm}(66 ; 80)$ & $75 \mathrm{~mm}(68 ; 86)$ & 0.24 \\
\hline VAS, upper extremities, mm, Me & $85 \mathrm{~mm}(80 ; 87)$ & $80 \mathrm{~mm}(72 ; 83)$ & 0.65 \\
\hline VAS, lumbar spine, $\mathrm{mm}, \mathrm{Me}$ & $68 \mathrm{~mm}(64 ; 78)$ & $68 \mathrm{~mm}(60 ; 72)$ & 0.82 \\
\hline VAS, lower extremities, $\mathrm{mm}, \mathrm{Me}$ & $82 \mathrm{~mm}(78 ; 85)$ & $67,5 \mathrm{~mm}(66 ; 72)$ & 0.14 \\
\hline Quality of life, ODI, score, Me & $74(76 ; 78)$ & $68(66 ; 74)$ & 0.36 \\
\hline Disability degree, NDI, score, Me & $48(44 ; 48)$ & $48(46 ; 48)$ & 0.78 \\
\hline
\end{tabular}

Note: $p^{*}$ is the confidence probability.

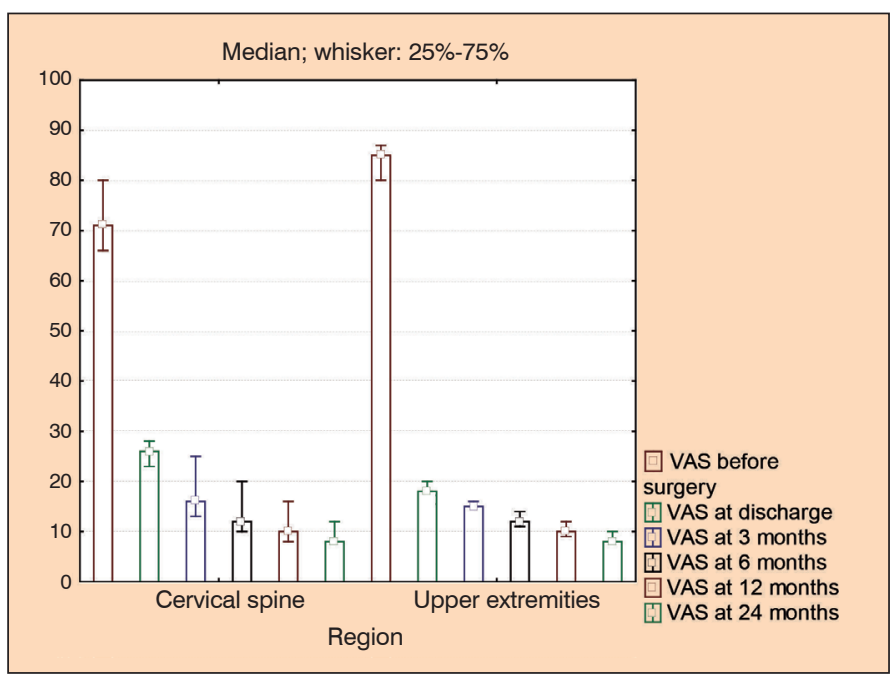

Figure 1. Changes in the pain level (VAS) in the cervical spine and upper extremities of group 1 patients. 


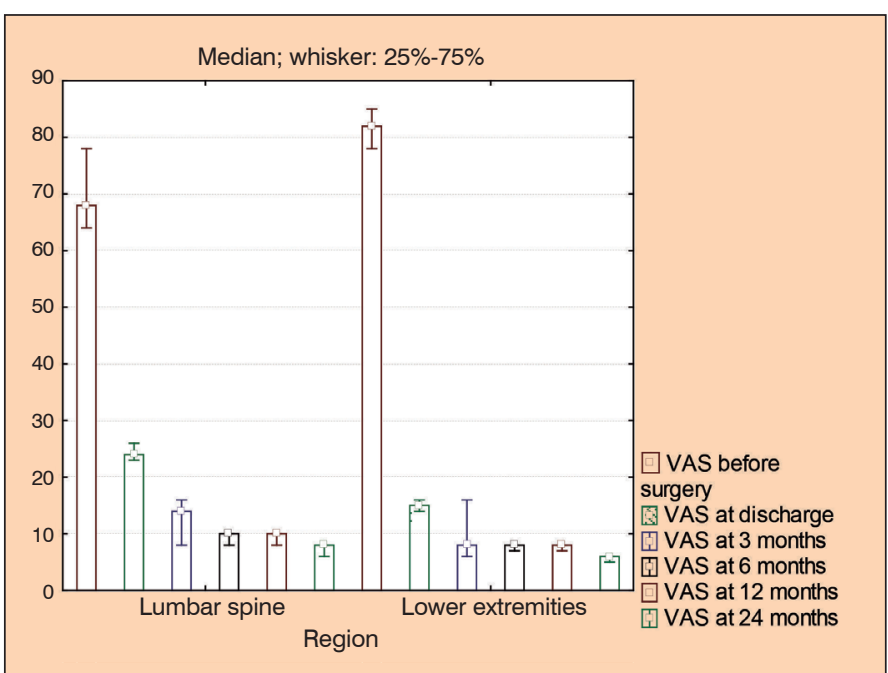

Figure 2. Changes in the pain level (VAS) in the lumbar spine and lower extremities of group 1 patients.

Table 3. Intergroup comparison of long-term surgical outcomes using VAS (mm).

\begin{tabular}{c|c|c|c}
\hline Region & Group I (n= 46) & Group II $(\mathbf{n}=\mathbf{5 1})$ & $\mathbf{p}^{*}$ \\
\hline Cervical spine & $8(8 ; 12)$ & $16(14 ; 22)$ & 0.01 \\
\hline Upper extremities & $8(8 ; 10)$ & $12(12 ; 16)$ & 0.02 \\
\hline Lumbar spine & $8(6 ; 8)$ & $14(14 ; 16)$ & 0.02 \\
\hline Lower extremities & $6(5 ; 6)$ & $15(12 ; 18)$ & 0.01 \\
\hline
\end{tabular}

Note: $p^{*}$ is the confidence probability.

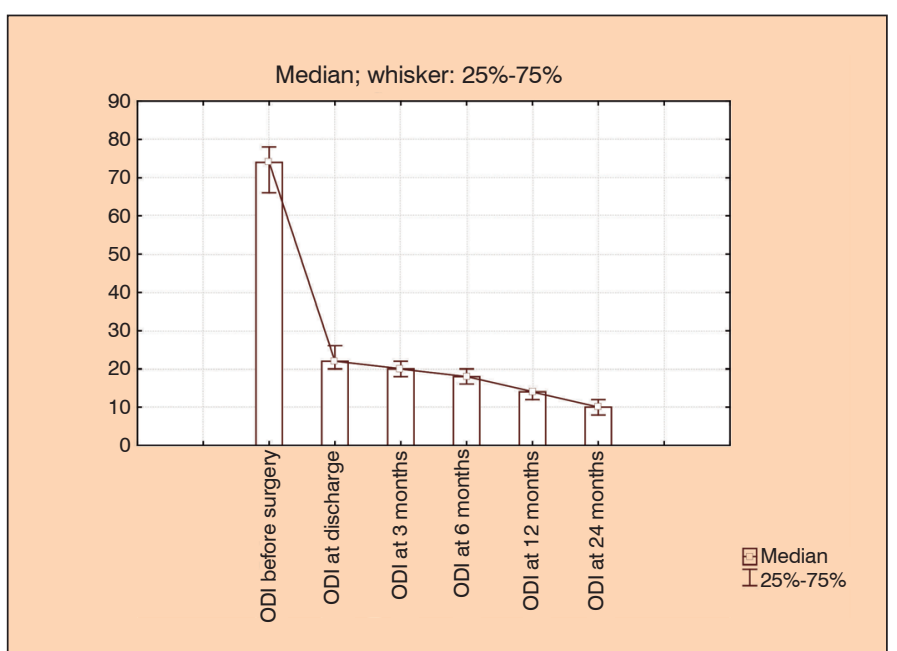

Figure 3. Changes in the functional state (ODI) of group 1 patients.

value $(p<0.001)$, and this improvement remained throughout follow-up period, with the NDI score decreasing from $74(76 ; 78)$ to 10 $(8 ; 12)(p=0.003)$ (Figure 4)

In the intergroup comparison of indices of disability associated with neck pain (NDI) and the lumbar spine (ODI) in the 24 months after surgical treatment, a statistically significant improvement was revealed in the functional state of group I operated on using the developed surgical approach to the treatment of patients with symptomatic tandem stenosis of the cervical and lumbar spine based on the preoperative clinical-instrumental algorithm $(p<0.05)($ Table 4).

Patients' subjective evaluation of surgical outcomes (Macnab scale) in 24 months (on average) after staged surgery gave predominantly excellent and good postoperative outcomes (Figure 5); there were no unsatisfactory outcomes marked. Satisfactory treatment outcomes were associated with incomplete regression of a neurologic deficit in the postoperative period and with concomitant minor neuropathic pain.
Comparative analysis of the long-term surgical outcomes (Macnab scale) at 24 months revealed statistically significantly greater satisfaction with the result of surgery in the prospective group of patients operated on using the developed surgical tactics based on the preoperative clinical-instrumental algorithm for treating patients with symptomatic tandem stenosis of the cervical and lumbar spine $p<0.05$ ) (Table 5)

Evaluation of the neurological outcome of surgery (Nurick scale) demonstrated complete regression or improvement of symptoms in most cases (Figure 6); no deterioration in the neurological status was detected.

Intergroup comparison of the long-term surgical outcomes (Nurick scale) at 24 months revealed a statistically significant improvement in the neurological status of patients operated on using the developed surgical tactics based on the preoperative clinical-instrumental algorithm for treating patients with symptomatic tandem stenosis of the cervical and lumbar spine $(p<0.05)$ (Table 6).

A comparative analysis revealed no statistically significant differences between the study groups by sex $(p=0.54)$, age $(p=0.36)$ and constitutional features $(p=0.22)$ (Table 1).

During the study, the patients in both groups had no adverse effects during placement of stabilizing structures. The comparative analysis showed a significantly higher number of postoperative complications in group $\|(p=0.0014)$ (Table 7).

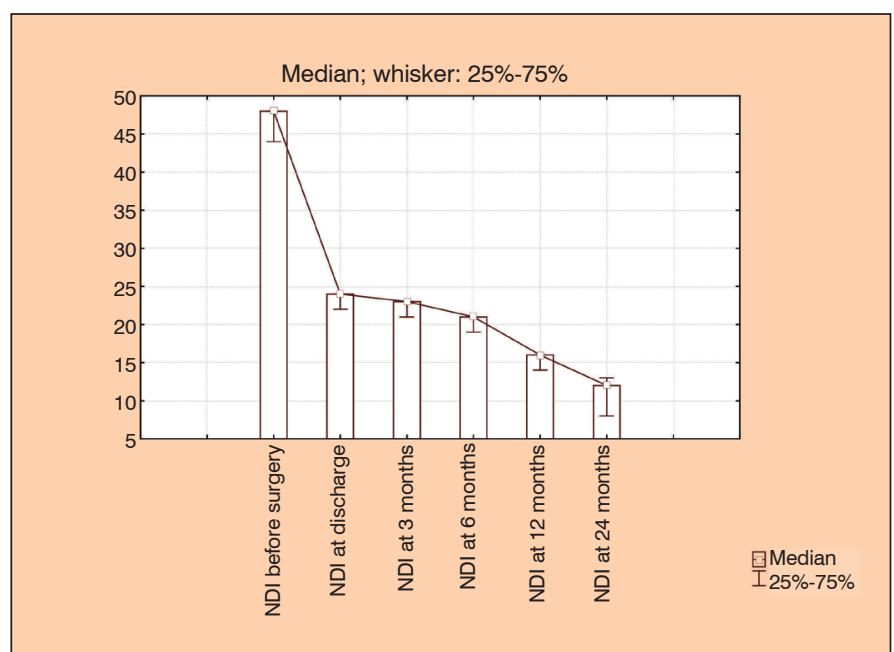

Figure 4. Changes in the extent of movement limitations (NDI) in the cervical spine in group 1 patients.

Table 4. Intergroup comparison of long-term surgical outcomes based on quality of life (ODI) and degree of movement limitation (NDI) (scores).

\begin{tabular}{c|c|c|c}
\hline Index & Group I (n=46) & Group II (n= 51) & $\mathbf{p}^{*}$ \\
\hline ODI & $10(8 ; 12)$ & $18(16 ; 20)$ & 0.03 \\
\hline NDI & $12(8 ; 14)$ & $20(14 ; 20)$ & 0.02 \\
\hline
\end{tabular}

Note: $p^{*}$ is the confidence probability.

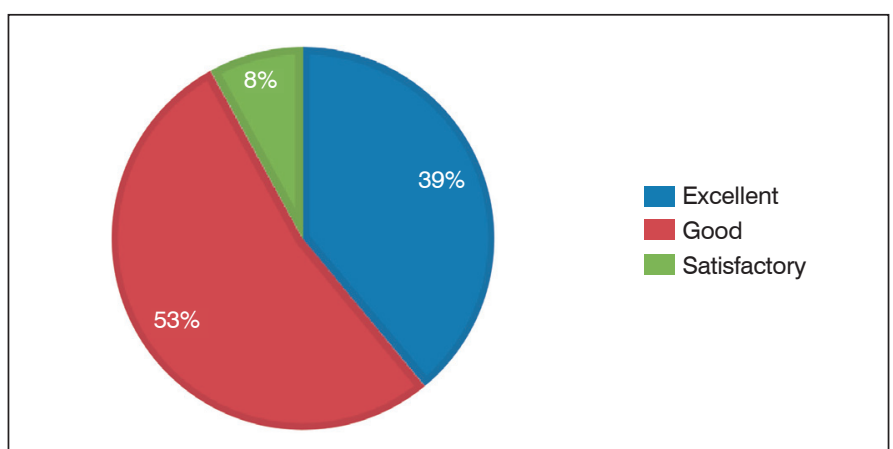

Figure 5. Subjective satisfaction with surgery (Macnab scale) in group 1 patients in the long-term postoperative period. 
In group I, seven (15\%) complications were verified. One (2\%) patient had injury of the dura mater of the dural sac during the transforaminal approach; in this case, the microsurgical technique enabled restoration of the anatomical integrity of the injured area. In the early postoperative period, 2 (4\%) patients were diagnosed with an intermuscular hematoma, drainage of which promoted healing of the postoperative wound within standard terms. Four (8.5\%) patients developed delayed complications; of them, two patients were verified with significant progression of the degenerative process in

Table 5. Intergroup comparison of long-term surgical outcomes using the Macnab scale.

\begin{tabular}{c|c|c|c}
\hline Outcome & Group I (n=46) & Group II (n=51) & p * \\
\hline Excellent & $18(39 \%)$ & $5(10 \%)$ & \\
Good & $24(53 \%)$ & $24(46 \%)$ & \multirow{2}{*}{$<0.001$} \\
\cline { 1 - 3 } Satisfactory & $4(8 \%)$ & $21(42 \%)$ & \\
\hline Unsatisfactory & - & $1(2 \%)$ &
\end{tabular}

Note: $p^{*}$ is the confidence probability.

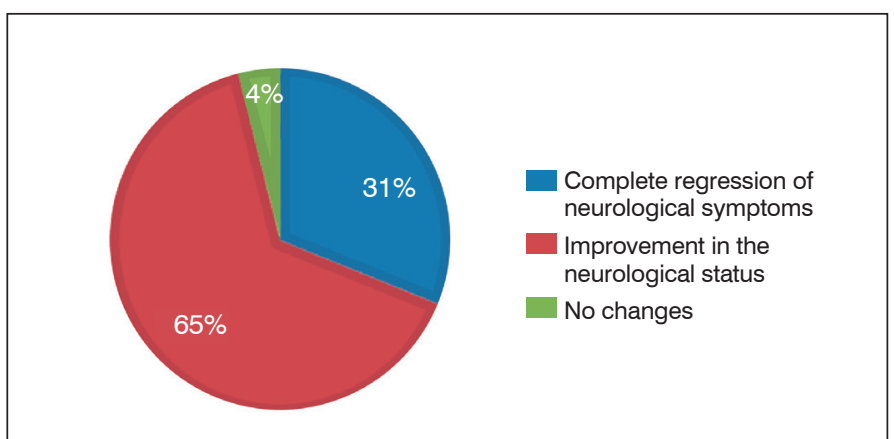

Figure 6. Changes in neurological symptoms (Nurick scale) in group 1 patients in the long-term postoperative period.

Table 6. Intergroup comparison of long-term surgical outcomes using the Nurick scale

\begin{tabular}{|c|c|c|c|}
\hline Condition & Group I $(n=46)$ & Group II $(n=51)$ & $\mathrm{p}^{*}$ \\
\hline $\begin{array}{c}\text { Complete regression } \\
\text { of symptoms }\end{array}$ & $14(31 \%)$ & $4(8 \%)$ & \multirow{4}{*}{$<0.001$} \\
\hline $\begin{array}{l}\text { Improvement of } \\
\text { neurological status }\end{array}$ & $30(65 \%)$ & $34(67 \%)$ & \\
\hline No changes & $2(4 \%)$ & $12(23 \%)$ & \\
\hline $\begin{array}{l}\text { Worsening of } \\
\text { symptoms }\end{array}$ & - & $1(2 \%)$ & \\
\hline
\end{tabular}

a segment adjacent to the surgery site without clinical data indicating compression of neural structures; in this case, conservative treatment improved the patients' condition. Two patients developed pseudarthrosis in the operated spine region, which required the implementation of revision of decompression/stabilization interventions from an anterior approach for the lumbar segment and a posterior approach for the cervical segment.

In group II, 16 (31\%) complications associated with cervical spine surgery and 19 (37\%) complications associated with lumbar spine surgery were registered. In six (11\%) intraoperative cases, there was iatrogenic injury to the dura mater of the dural sac or spinal root, which required microsurgical suturing of a defect with additional application of fibrin glue. In the early postoperative period, six (11\%) patients developed a hematoma in the postoperative wound area with soft tissue infection being detected in three cases - drainage and local antiseptics facilitated elimination of the infectious process. Delayed postoperative complications occurred in 23 (45\%) patients; of these, 19 (37\%) patients underwent revision surgery for disc herniation in adjacent segments in the setting of degenerative process progression, pseudarthrosis in the operated segments, clinically significant inadequate primary decompression, and fixing structure instability. In four (8\%) cases, relapse of neurological symptoms was caused by the formation of postoperative epidural fibrosis in the absence of radiologic signs of spinal canal and intervertebral foramen narrowing as well as signs of pathological mobility according to multispiral computed tomography with myelography. In these cases, courses of conservative therapy significantly reduced the pain level.

\section{DISCUSSION}

The developed surgical tactics based on the preoperative clinical-instrumental algorithm for the treatment of the patients with symptomatic tandem stenosis of the cervical and lumbar spine significantly improved the functional state of patients. This is confirmed by the minimal ODI and NDI scores and a low pain level (VAS) in the cervical and lumbar spine, as well as in the upper and lower extremities in the long-term postoperative period.

The differentiated and personalized use of standard surgical techniques for staged decompressive-stabilizing surgical interventions enabled effective anterior and posterior decompression, depending on the location of the pathomorphological substrate in the cervical spine and minimally invasive stabilization of the operated segments at the lumbar level with a smaller number of formations of pseudoarthrosis and epidural fibrosis. This was confirmed by a smaller number of postoperative complications in group I - 15\%, compared to group $\|-68 \%(p=0.0014)$.

Therefore, precise elimination of the pathological substrate

Table 7. Characterization of identified complications in the study group patients.

\begin{tabular}{|c|c|c|c|c|c|}
\hline \multirow[b]{2}{*}{ Condition } & \multicolumn{2}{|c|}{ Retrospective group $(n=51)$} & \multicolumn{2}{|c|}{ Prospective group $(n=46)$} & \multirow[b]{2}{*}{$\mathbf{p}^{*}$} \\
\hline & $\begin{array}{c}\text { Cervical spine } \\
\text { surgery }\end{array}$ & $\begin{array}{l}\text { Lumbar spine } \\
\text { surgery }\end{array}$ & $\begin{array}{l}\text { Cervical spine } \\
\text { surgery }\end{array}$ & $\begin{array}{c}\text { Lumbar spine } \\
\text { surgery }\end{array}$ & \\
\hline Intraoperative complications, n, \% & $3(6 \%)$ & $3(6 \%)$ & $0(0 \%)$ & $1(2 \%)$ & \multirow{3}{*}{0.01} \\
\hline Root injury & - & 2 & - & - & \\
\hline Early postoperative complications, n, $\%$ & $2(4 \%)$ & $4(8 \%)$ & $1(2 \%)$ & $1(2 \%)$ & \\
\hline Postoperative hematoma & 1 & 2 & 1 & 1 & 0.02 \\
\hline Long-term postoperative complications, n, \% & $11(22 \%)$ & $12(24 \%)$ & $2(4 \%)$ & $2(4 \%)$ & \multirow{5}{*}{$<0.001$} \\
\hline Disc herniation adjacent to the surgery level & 1 & 2 & 1 & 1 & \\
\hline Pseudarthrosis & 3 & 4 & 1 & 1 & \\
\hline Instability of fixation device & 1 & - & - & - & \\
\hline Persistence of symptoms due to insufficient decompression & 2 & 2 & - & - & \\
\hline
\end{tabular}


primary in the cervical spine and early implementation of the second surgical stage in patients with symptomatic tandem stenosis of the cervical and lumbar spine, as well as the combination of optimal decompression of the neural structures with minimally invasive decompressive-stabilizing techniques, enables a significant reduction in neurological symptoms, a decrease in pain level, an improvement in patients' quality of life, and a reduced risk of intraand postoperative complications.

Combined stenotic degenerative diseases of two or more spinal regions are diagnosed in 5-25\% of cases; at the same time, despite the presence of neuroimaging signs, tandem stenoses are often asymptomatic. $5,10,19$

Simultaneous stenosis of several spinal segments causes the development of various neurological symptoms, such as myelopathy, radiculopathy, and caudogenic intermittent claudication. ${ }^{25}$ This leads to the problems in diagnosing and choosing the treatment tactics. ${ }^{7,18}$ Combined stenosis of the spinal canal has a reciprocal clinical complication both before surgery and in the postoperative period, due to prolonged positioning on the operating table. ${ }^{26}$

Approaches to surgical treatment of patients with tandem stenoses are currently not sufficiently studied due to the symptom polymorphism and the multifactorial pathomorphological substrate, which cause narrowing of the spinal canal at several levels. Thus, some authors recommend decompression on clinically significant levels but indicate high risks of simultaneous surgery in several regions of the spinal column, which are associated with the duration of surgical intervention, significant intraoperative trauma of soft tissues and blood loss, and aggravation of neurological manifestations due to the forced position. ${ }^{4,7,27}$ For this reason, the concept of staged surgery in patients with tandem stenoses of the spinal canal has been suggested, which is aimed at primary manipulations in the area of the predominant clinical symptoms. ${ }^{10,19,28}$

Currently, there are no studies devoted to the dynamic assessment of clinical symptoms, surgical treatment tactics, and methods for post-operatively recording outcomes in patients with tandem stenoses of the cervical and lumbar spine in the Pubmed database and Russian-language literature are also absent.

We performed a prospective analysis of surgical treatment outcomes in patients with symptomatic tandem stenosis of the cervical and lumbar spine who were operated on using the developed surgical tactics based on the differential clinical-instrumental algorithm. The algorithm involves factors affecting the clinical outcome: medical history (disease duration), and features of the chosen surgical tactics (the spinal region to be operated first, the volume of decompression, and the time interval between surgical stages). ${ }^{22}$

According to the ODI and NDI scores, changes in postoperative pain intensity and functional state of patients in the study group did not significantly differ from the published data on surgical treatment of isolated stenoses of the spinal canal. ${ }^{1,3,13}$ Comparative analysis of retrospective group revealed the best clinical outcomes (according to the VAS, ODI, NDI, and the Macnab and Nurick scales) in the long-term period, which confirmed the efficacy of the developed differential surgical tactics for treating patients with tandem stenoses of the cervical and lumbar spine. In addition, the comparative intergroup analysis confirmed a smaller number of adverse outcomes in the prospective study group due to the optimal volume of decompression at the cervical level in the presence of a myelopathic lesion, and effective minimally invasive stabilization of the operated segments in the lumbar spine.

The surgical techniques used in the study group patients are standard and have been widely used by various groups of authors in the surgical treatment of patients with isolated stenoses of the spinal canal at the cervical and lumbar levels. ${ }^{14,15}$ However, approaches to the step-by-step implementation of surgical interventions and the timing of their implementation, the personified use of ventral and dorsal surgical techniques, as well as the priority of applying decompressive techniques before decompressive-stabilizing techniques in patients with tandem stenosis, were absent.

Our findings are promising for further improvement of the complex therapeutic and diagnostic tactics in patients with degenerative diseases of the spinal column.

\section{Limitations of the study}

Limitations of this study is the small sample of analyzed patients, due to the rare occurrence of symptomatic tandem stenoses of the cervical and lumbar spine, and the heterogeneity of the surgical techniques used for decompression and stabilization of the structures of the spinal canal; and an insufficient mean follow-up time (24 months) associated with the follow-up protocol stated in the study. Undoubtedly, it is necessary to continue multicenter studies in a larger number of respondents, and to perform a detailed study of long-term clinical-instrumental outcomes with a follow-up period of 5 years or more to investigate the long-term efficacy of the developed surgical tactics and the use of various decompressive and decompressive-stabilizing techniques of surgical interventions.

\section{CONCLUSION}

The multicenter analysis of the efficacy of the surgical tactics based on the differential clinical-instrumental algorithm in patients with symptomatic tandem stenosis of the cervical and lumbar spine revealed its high clinical and radiological efficacy. The differentiated use of decompression/stabilization techniques enabled rational and radical surgery associated with a reduced number of adverse outcomes, which allowed an early onset of active rehabilitation measures in the prospective group of patients, which objectively improved the long-term clinical and functional outcomes.

All authors declare no potential conflict of interest related to this article.

CONTRIBUTION OF THE AUTHORS: Each author made significant individual contributions to this manuscript. VAB (0000-0003-4349-7101)* and AAK $(0000-0001-9039-9147)^{\star}$ were the main contributors to the drafting of the manuscript. VAB, AAK, VVS (0000-0001-5135-8115)* performed the surgery and patient follow-up, and gathered clinical data. AAK, YYP (0000-0003-2633-7149)* evaluated the data from the statistical analysis. AAK, VVS and YYP performed the literature search and review of the manuscript, and contributed to the intellectual concept of the study. ${ }^{*}$ ORCID (Open Researcher and Contributor ID).

\section{REFERENCES}

1. Byvaltsev VA, Kalinin AA, Okoneshnikova AK, Kerimbayev TT, Belykh EG. [Facet fixation in combination with interbody spondylodesis: comparative analysis and clinical experience of a new method of surgical treatment of patients with degenerative diseases of the lumbar spine]. Annals of the Russian Academy of Medical Sciences. 2016;71(5):375-83. [Article in Russian]

2. Dreval' MD, Gushcha AO. [Surgical treatment of cervical spondylogenous myelopathy by laminoplasty: a literature review]. Spine Surgery. 2015;2:44-50. [Article in Russian]

3. Belykh EG, Kalinin AA, Patel AA, Miller EJ, Bohl MA, Stepanov IA et al. Apparent diffusion coefficient maps in the assessment of surgical patients with lumbar spine degeneration. PLoS ONE. 2017;12(8): e0183697.

4. Overley SC, Kim JS, Gogel BA, Merrill RK, Hecht AC. Tandem Spinal Stenosis: A
Systematic Review. JBJS Rev. 2017;5(9):e2.

5. Ghobrial GM, Oppenlander ME Maulucci CM, Viereck M, Prasad S, Sharan AD, et al. Management of asymptomatic cervical spinal stenosis in the setting of symptomatic tandem lumbar stenosis: a review. Clin Neurol Neurosurg. 2014;124:114-8.

6. Bajwa NS. Toy JO, Young EY. Ahn NU. Is congenital bony stenosis of the cervical spine associated with congenital bony stenosis of the thoracic spine? An anatomic study of 1072 human cadaveric specimens. J Neurosurg Spine. 2012;17(1):24-9.

7. Matsumoto $Y$, Harimaya K, Doi T, Kawaguchi K, Okada S, Inoguchi A, et al. Clinical characteristics and surgical outcome of the symptomatic ossification of ligamentum flavum at the thoracic level with combined lumbar spinal stenosis. Arch Orthop Trauma Surg. 2012;132(4):465-70 
8. Krishnan A, Dave BR, Kambar AK, Ram H. Coexisting lumbar and cervical stenosis (tandem spinal stenosis): an infrequent presentation. Retrospective analysis of singlestage surgery (53 cases). Eur Spine J. 2014;23(1):64-73.

9. Eskander MS, Aubin ME, Drew JM, Eskander JP, Balsis SM, Eck J, et al. Is there a difference between simultaneous or staged decompression for combined cervical and lumbar stenosis. J Spinal Disord Tech. 2011:24(6):409-13.

10. Miyazaki M, Kodera R, Yoshiiwa T, Kawano M, Kaku N, Tsumura H. Prevalence and distribution of thoracic and lumbar compressive lesions in cervical spondylotic myelopathy. Asian Spine J. 2015;9(2):218-24.

11. Costandi, S, Chopko B, Mekhail M, Dews T, Mekhail N. Lumbar spinal stenosis: therapeutic options review. Pain Pract. 2015;15(1):68-81.

12. Kreiner DS, Shaffer WO, Baisden JL, Gilbert TJ, Summers JT, Toton JF, et al. An evidencebased clinical guideline for the diagnosis and treatment of degenerative lumbar spinal stenosis (update). Spine J. 2013;13(7):734-43

13. Arnold PM. Minimally invasive spinal surgery and spinal stenosis. J Neurosurg Spine. 2015;22(4):337-8.

14. Jacobson RE, Granville M, Berti A. Minimally invasive anterior cervical discectomy without fusion to treat cervical disc herniations in patients with previous Cervical Fusions. Cureus. 2017:9(4):e1131.

15. Lebedev VB, Epifanov DS, Kostenko GV, Ghodivala TS, Nurmukhametov RM, Pedyash $\mathrm{NV}$, et al. [Minimally invasive reconstruction of the spinal canal with degenerative lumbar stenosis]. Spine Surgery. 2017;14(3):67-73. [Article in Russian]

16. Nagata $K$, Yoshimura N, Hashizume H, Ishimoto $Y$, Ishimoto $Y$, Muraki S, et al. The prevalence of tandem spinal stenosis and its characteristics in a population-based MRI study: The Wakayama Spine Study. Eur Spine J. 2017;26(10):2529-35.

17. Menon VK, Raniga SB, AI Busaidi AQ. MRI morphology of surgically treated lumbar canal stenosis: a retrospective study. J Spinal Disord Tech. 2015;28(1):12-8.

18. Lau YYO, Lee RKL, Griffith JF, Chan CLY, Law SW, Kwok KO. Changes in dural sac caliber with standing MRI improve correlation with symptoms of lumbar spinal stenosis. Eur Spine J. 2017;26(10):2666-75
19. Yamada $T$, Yoshii $T$, Yamamoto $N$, Hirai $T$, Inose $H$ Kato $T$, et al Clinical outcomes of cervical spinal surgery for cervical myelopathic patients with coexisting lumbar spinal canal stenosis (tandem spinal stenosis) a retrospective analysis of 297 cases. Spine (Phila Pa 1976). 2018;43(4):E234-41.

20. Baikov ES, Baikalov AA. [Relationship between biomechanical and biochemical parameters of spinal motion segments and recurrent lumbar disc herniation]. Spine Surgery. 2017;4(14):61-8. [Article in Russian]

21. Afaunov AA, Basankin IV, Kuzmenko AV, Shapovalov VK. [Analysis of reasons for revision surgery in patients treated for degenerative lumbar spinal stenosis]. Kuban Research Medical Gazette. 2013;(7):173-6. [Article in Russian]

22. Byvaltsev VA, Krutko AV, Shepelev VV, Kalinin AA. [Results of stage surgical treatment of patients with tandem-stenoses of the cervical and lumbosacral spine]. Spine Surgery. 2017;14(2):50-62

23. Pfirrmann C, Metzdorf A, Zanetti M, Hodler J, Boos N. Magnetic resonance classification of lumbar intervertebral disc degeneration. Spine (Phila Pa 1976). 2001;26(17):1873-8

24. Bridwell KH, Lenke LG, McEnery KW, Baldus C, Blanke K. Anterior structural allografts in the thoracic and lumbar spine. Do they work if combined with posterior fusion and instrumentation in adult patients with kyphosis or anterior column defects? Spine (Phila Pa 1976) 1995:20(12):1410-8

25. Rahmanian A, Minagar S, Rakei SM, Taghipoor M, Mehrabani G, Razm kon A. A Survey of Tandem Spinal Stenosis in Shiraz, Southern Iran. Neurosurgery Quarterly. 2014;25(2):1-4.

26. Adamova B, Bednarik J, Andrasinova T, Kovalova I, Kopacik R, Jabornik M, et al. Does lumbar spinal stenosis increase the risk of spondylotic cervical spinal cord compression? Eur Spine J. 2015;24(12):2946-53

27. Hu PP, Yu M, Liu XG, Liu ZJ, Jiang L. Surgeries for Patients with Tandem Spinal Stenosis in Cervical and Thoracic Spine: Combined or Staged Surgeries? World Neurosurg 2017:107:115-23

28. Molinari RW, Flanigan R, Yaseen Z. Tandem spinal stenosis (TSS): literature review and report of patients treated with simultaneous decompression. Curr Orthop Pract. 2012;23(4):356-63. 